\title{
Accountants In Demand: Survey Of Business Students Suggests That Nothing Will Motivate Non-Accounting Majors To Be Accounting Majors
}

Dahli Gray, Jones International University

Orapin Duangploy, University of Houston-Downtown

Clemense Ehoff Jr., R. K. Tongue Co. Inc.

\begin{abstract}
Student enrollment in accounting programs in the state of Maryland increased 12\% from 2006 to 2007 (MACPA, 2007). This paper presents actual and possible responses to demand exceeding supply of accounting professionals and professors. Responses to the shortage of supply to meet the demand include outsourcing the work (e.g., tax returns completed in India) to expanding university offerings. This paper addresses the shortage of terminally qualified (i.e., doctoral degree) accounting professors. One resolution to the professor shortage has been to use more adjunct faculty. Survey research results reveal that business majors who are not accounting majors are not willing to consider becoming accounting majors. Current accounting majors rank salary, meaningful work and advancement opportunities as the top reasons for career selection. The non-accounting majors hold similar values, but clearly state that there is nothing that would motivate them to be accountants.
\end{abstract}

Keywords: Career choices, Business major, Accounting major, Teacher qualifications, Survey research student opinions

\section{INRODUCTION}

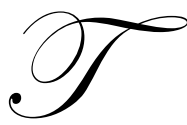

he crisis in accountancy won't be easy for academics or practitioners to rectify, but describing the problem and suggesting a proposal to remedy accountancy's flaws is a start on the road to ending it." (Clinton, 2007, p. 30) This paper responds to Clinton's (2007) idea of describing the problem and suggesting proposals to end it. Business students' reasons for selecting or rejecting the accounting major are addressed in this paper. There is lack of supply to meet the demand for accountants. Non-accounting majors state that there is nothing that would motivate them to be accounting majors. The accounting majors ranked the following employment attributes as the most important in their decision to select the accounting major: salary, advancement opportunities, meaningful work in a stimulating environment, training and continued education provided and funded, comprehensive resources (e.g., technology and software) to get the job done, and quality and affordable health coverage. The paper is organized as follows: supply of accountants, demand for accountants, supply of accounting professors, demand for accounting professors, research process, research results, summary and conclusion.

\section{SUPPLY OF ACCOUNTANTS}

Sanders (2005) reported the available supply of accounting graduates from 1988 through 2004 in a study sponsored by the American Institute of Certified Public Accountants (AICPA). Selected information from the report is presented in Table 1. 
Table 1

Accounting Degrees Awarded by All Schools

\begin{tabular}{llll}
\hline Academic & Bachelor & Master & Total \\
Year & Graduates & Graduates & Graduates \\
$1988-89$ & 52,500 & 5,230 & 57,730 \\
$2003-04$ & 40,420 & 13,340 & 53,760 \\
\hline
\end{tabular}

Note. Taken from page 4 of the American Institute of Certified Public Accountants (AICPA) (2005) "The Supply of Accounting Graduates and the Demand for Public Accounting Recruits-2005.” The American Institute of Certified Public Accountants. Retrieved March 9, 2008, from http://ceae.aicpa.org/NR/rdonlyres/11715fc6-f0a7-4ad6-8d28-

6285cbe77315/0/supply_demandreport_2005.pdf

There was a thirteen percent rise in the number of bachelor degrees and seven percent rise in graduate degrees in the academic year 1988-89 compared to the academic year 1987-88 (Sanders, 2005). This "spike" may have been caused by the AICPA passage of the 150-hour education requirement. Students may have accelerated their degree completion schedule in order to satisfy existing CPA exam requirements before implementation of the 150-hour requirement (Madison, 2005). Otherwise, most students would be required to incur tuition for an additional 30 credit hours (i.e., 30 beyond the standard 120 required for a bachelors degree), and forego a year of earnings (Madison, 2005).

Table 1 reveals the annual number of bachelors and masters graduates dropped a total of $101 / 2$ percent (i.e., from 57,730 in 1988 to 53,760 in 2004). This statistic is objective, but it is not necessarily a valid measurement of the supply of accountants. It is a measure people graduating with degrees in accounting. It is possible for people to become accountants with a bachelor or graduate degree in something other than accounting. They can take accounting courses to become accountants without getting an accounting degree. A degree in accounting is not required for a person to sit for the Certified Public Accountant (CPA) exam. Requirements for taking the CPA exam can be located via the web site for the National Association of State Boards of Accountancy (i.e., www.nasba.org ). Getting a true measure of the supply of accountants is difficult.

Many academic programs award degrees where accounting is a major or specialization that does not appear on the degree or in the degree statistics. Many individuals who originally earn a degree in something other than accounting return to school to take accounting and related courses so that they can work as accountants. These students do not necessarily earn another degree that could be included in the data used for an updated AICPA report or any report regarding the actual number of people who meet the academic accounting requirements.

It is easier to gather information on the number of people taking and/or passing the Certified Public Accountant (CPA) exam. This paper is not about the supply and demand for CPAs. Robert Half International (2007) completed a study addressing what is important to young CPAs. The attributes included in the Robert Half (2007) survey and findings of the CCH Young Accounting Professionals Survey as summarized in the Robert Half (2007) article are used as the basis of the survey (see Appendix A) administered for this paper. The survey results of this research support the prior research. This paper's survey results reveal that current students who are not accounting majors are not open to becoming accountants. Before presenting the survey result details regarding supply, examples of existing evidence that demand continues to exceed supply is briefly summarized.

\section{DEMAND FOR ACCOUNTANTS}

Employment for accountants and auditors will likely grow in the range of 18 to 26 percent through 2014 (U.S. Department of Labor, 2007). Bonacum and Allen (2006) noted that within 14 years, 75 percent of American Institute of Public Accountants (AICPA) members will reach retirement age (2006). IndiaPWire (2006) reported that " $\ldots$ as many as 360,000 US tax returns were prepared in India in 2006." IndiaPWire (2006) reports that “... at least 1.6 million [US tax] returns will be prepared ... in [India] in $2011 \ldots$ the potential is much larger at 22 million returns per year by 2011." 
Elliott (2007) predicts that "[i]n other states, when the 150-hour requirement began, the number of students taking the CPA Exam dipped, and this is likely to occur in New York" when the requirement goes into effect in 2009. Penix (2006) reported that a "nationwide shortage [of public accountants] has plagued the industry for at least a decade but the post-Katrina supply and demand surge intensified it locally" in New Orleans. Penix (2006) stated that "[i]t's not only CPAs but all accountants." Penix (2006) reported that "[f]aced with a mandatory nationwide increase in instructional hours from 120 to 150 to earn a degree and take a licensing exam, accounting firms say some math students are choosing professions such as informational technology and engineering." Penix (2006) concluded that “... [d]emand increased with passage of 2002's Sarbanes-Oxley Act, corporate governance guidelines that require more disclosure regarding corporate financial transactions." To develop the supply of accountants, academic programs need accounting professors. The accounting professor supply is discussed next.

\section{SUPPLY OF ACCOUNTING PROFESSORS}

Elliott (2007) concludes that we "... have to navigate through a critical national shortage of qualified PhDs to teach accounting." Klein (2007) reported that a "large cohort of senior faculty is due to retire soon and there are too few new PhDs to replace them. The shortage is particularly acute at Tier I universities and within sub-disciplines like tax and auditing. Fewer students appear to be enrolling in $\mathrm{PhD}$ programs in accounting and fewer $\mathrm{PhD}$ graduates are opting for academic careers (as opposed to careers in consulting)."

"Without qualified faculty, schools might be forced to cut enrollments, even accounting programs. In addition, slots may be filled by less qualified candidates, which may adversely affect the training of accountants in the future." (New Accountant USA, n.d., p. 12) Noland, Francisco and Sinclair (2007) reported that “... from 2005 to 2008 , the overall supply of new accounting PhDs will meet only $49.9 \%$ of demand ... the supply of new $\mathrm{PhDs}$ specializing in audit and tax will meet only $22.8 \%$ and $27.1 \%$ needed in these disciplines, respectively."

The authors of this paper did not do additional research regarding the supply of accounting professors. However, suggestions are presented next regarding ways to address the shortage of accounting professors.

\section{ACCOUNTING PROFESSORS QUALIFICATIONS REDEFINED}

Defining who can serve as an accounting professor is the easiest solution to the shortage of so-called terminally qualified professors. About thirty years ago, a Masters degree (typically a Masters of Business Administration or MBA) and CPA combination were qualifications to be considered to be terminally qualified. Due to the 150-credit hour requirement relative to earning the CPA designation, there are many people with the Masters plus CPA combination. Returning to the definition of a Masters plus CPA as being terminally qualified would change the supply of accounting professors situation from shortage to abundance.

Keeping the existing productive professors with doctoral degrees in the classroom beyond the typical retirement age of about 65 is another approach. In some colleges and universities, the professors with doctoral degrees do not spend a great deal of time in the classroom. They often have teaching assistants who do the in-class duty for them while they provide service to the college or university. Perhaps decreasing the service requirements and increasing the in-class teaching is one response to the need for more professors in the classroom.

The Executives-in-Residence approach has brought experience to the classroom. Part-time (i.e., adjunct) faculty have also been popular approach to addressing the shortage of accounting professors. Typically, these people work full-time as accountants and teach on the side. They bring the richness of their professional experience to the classroom. The Executive-in-Residence and adjunct faculty typically bring a valuable depth of knowledge based on experience plus continued professional education (CPE) mandated for maintaining the CPA license. They typically lack the breadth of knowledge that professors with doctoral degrees bring to the classroom. Typically, neither group has been taught how to teach.

Professors with doctoral degrees can create and manage the online classroom content. The professors with a masters degree with CPA to teach the courses is another response to the supply not meeting the demand for 
accounting professors. The partially online (i.e., hybrid) courses expand the opportunity for professors with doctoral degrees to impart and/or develop student knowledge and skills. For example, some programs have one-third of the course in the traditional face-to-face classroom and the other two-thirds of the course online. Professors with doctoral degrees could expand contact from one to three courses. If the current course load is three courses, then it could expand to nine courses. This is not an approach embraced by existing tenured faculty. However, it is an option.

This paper does not present original research on the accounting professor crisis. This paper does present original research on accountants. The research process and results are presented next.

\section{RESEARCH PROCESS}

As mentioned earlier, the survey instrument (see Appendix A) was built using some of the attributes found in the Robert Half International (2007) study and the Findings From the CCH Young Accounting Professionals Survey (March 2007 . Students chosen to participate in this study were graduate and undergraduate students taking courses in the fall 2007 semester from five universities. The universities were public state, private and online forprofit. There was no difference in the responses based on the type of university. They were enrolled in either faceto-face classes or online accounting courses. The results of the survey are shown in the following tables.

\section{RESEARCH RESULTS}

Table 2 compares the employment attributes ranked by graduate versus undergraduate business majors. The survey instrument is appendix $\mathrm{A}$ at the end of the paper.

Table 2

Employment Attributes Ranked by

Graduate versus Undergraduate Business Majors

$1=$ most important to $9=$ least important

\begin{tabular}{|c|c|c|}
\hline & Graduates & Undergraduates \\
\hline Salary & 1 & 1 \\
\hline $\begin{array}{l}\text { Meaningful work in a stimulating } \\
\text { environment }\end{array}$ & 2 & 2 \\
\hline Advancement opportunities & 3 & 3 \\
\hline $\begin{array}{l}\text { Training and continued education } \\
\text { provided and funded }\end{array}$ & 6 & 4 \\
\hline $\begin{array}{l}\text { Comprehensive resources (e.g., } \\
\text { technology and software) to get the job } \\
\text { done }\end{array}$ & 4 & 6 \\
\hline Quality and affordable health coverage & 5 & 5 \\
\hline Compressed or flexible work weeks & 7 & 7 \\
\hline Ability to work remotely & 8 & 8 \\
\hline Little or no travel & 9 & 9 \\
\hline Other & $\begin{array}{l}\text { Growth, less than } 30 \text { minute commute, } \\
\text { nice people, benefits, company culture, } \\
\text { family friendly }\end{array}$ & Paid vacation \\
\hline
\end{tabular}

Respondents: Graduates $=160$ Undergraduates $=162$ 
Table 3

Employment Attributes Ranked by

Graduate versus Undergraduate Accounting Majors

$1=$ most important to $9=$ least important

\begin{tabular}{|c|c|c|}
\hline & Graduates & Undergraduates \\
\hline Advancement opportunities & 1 & 2 \\
\hline Salary & 2 & 1 \\
\hline $\begin{array}{l}\text { Meaningful work in a stimulating } \\
\text { environment }\end{array}$ & 3 & 3 \\
\hline $\begin{array}{l}\text { Training and continued education } \\
\text { provided and funded }\end{array}$ & 4 & 4 \\
\hline $\begin{array}{l}\text { Comprehensive resources (e.g., } \\
\text { technology and software) to get the job } \\
\text { done }\end{array}$ & 5 & 6 \\
\hline Quality and affordable health coverage & 6 & 5 \\
\hline Compressed or flexible work weeks & 7 & 7 \\
\hline Ability to work remotely & 8 & 8 \\
\hline Little or no travel & 9 & 9 \\
\hline Other & Quality of location & $\begin{array}{l}\text { Social events } 9 \text { dress code } 9 \text { have a nice } \\
\text { office } 10 \text { friendly co-workers } 10\end{array}$ \\
\hline
\end{tabular}

Respondents: Graduates $=140$ Undergraduates $=136$

Table 4

Impact of 150-Hour Requirement on Accounting Majors

\begin{tabular}{|l|c|c|}
\hline & Graduate & Undergraduate \\
\hline Not going to take CPA exam & 0 & 0 \\
\hline Get a Masters degree & 140 & 136 \\
\hline Other & & \\
\hline
\end{tabular}

Respondents: Graduates $=140$ Undergraduates $=136$

Table 5

What it would take to get a Non-Accounting Major to Become an Accounting Major

\begin{tabular}{|l|c|c|}
\hline & Graduate & Undergraduate \\
\hline More money & & \\
\hline Little or no travel & & 162 \\
\hline Other & 160 & \\
\hline
\end{tabular}

Respondents: Graduates $=160$ Undergraduates $=162$

Employment attribute rankings by graduate and undergraduate business majors (Table 2) were nearly identical. The only difference in ranking was between comprehensive resources and training. Salary (1), meaningful work (2), and advancement opportunities (3) showed the highest rankings.

Employment attribute rankings by graduate and undergraduate accounting majors (Table 3) showed similar results. Salary, meaningful work, and advancement opportunities scored in the top three. Graduate accounting majors ranked advancement opportunities first and salary second. Undergraduate accounting majors ranked salary first and advancement opportunities second. There was a similar "flip-flop" in rankings between comprehensive resources and quality and affordable health coverage. 
There was little difference in employment attribute rankings between business majors and accounting majors. Salary, meaningful work, and advancement opportunities topped the rankings in both tables.

Accounting major respondents said that they planned to take the CPA exam, as well as get a Master's degree. When asked what it would take to get a non-accounting major to become an accounting major, all respondents, both graduate and undergraduate indicated that nothing would change their minds. The respondents were in the midst of their first or second accounting course.

Comparing the Robert Half (2007) survey results to the survey results reported in this paper points out the focus on salary. The $\mathrm{CCH}$ Young Accounting Professionals survey revealed that having the resources to complete the job was most important to young CPAs. Access to the latest technology and software were second and third most important. The fourth most important was the ability to work remotely, which was ranked last by the students surveyed for this paper. The Robert Half (2007) survey of employers revealed that salary and career advancement opportunities were considered key attributes for recruiting young professionals. The survey results reported in this paper are consistent with the Robert Half (2007) findings.

\section{SUMMARY AND CONCLUSIONS}

The supply of accounting professionals and professors is not currently meeting demand. The survey research results reported in this paper are based on the opinions of undergraduate and graduate business majors. Those majoring in accounting were surveyed to see if preferences were different. The preferences were similar. The survey results of this paper support the findings of earlier research. It is important to continue the research process to explore if values have changed. It appears that prior and current accounting majors are motivated by salary, advancement opportunities and meaningful work in a stimulating environment.

\section{OUTLOOK}

The accounting profession absorbed several blows to its reputation. The financial failures of Enron, Worldcom, and others, along with the demise of the Arthur Andersen accounting firm, may have given the accounting profession "scars" and driven away some prospective accountants. However, the demand for accountants, both public and private, seems to have absorbed this setback as well. Increased reporting and compliance requirements, culminating in the Sarbanes-Oxley Act of 2002, formed a solid foundation to support continued growth in accountant demand.

Although the supply of accounting graduates has steadily grown in recent years, it has yet to reach the level achieved in 1988, the year when the 150-hour education requirement was passed. The audit failures of the 1990s along with the demise of the Arthur Andersen accounting firm caused substantial damage the reputation of accounting firms specifically and accountants in general. Despite these setbacks (and in some way because of them), demand for accounting graduates has increased dramatically. Fueled by increased reporting and compliance requirements (such as the Sarbanes-Oxley Act of 2002) and the anticipated retirement of accountants, the demand for accountants is strong and will likely see double-digit growth far into the future. It is reasonable to assume that accounting education at the undergraduate and graduate levels will grow as well.

\section{AUTHOR INFORMATION}

Dahli Gray, DBA, CPA, CMA, CFE is with Jones International University. She has published numerous articles in such journals as the Journal of Accounting Research, Journal of Accountancy, International Business \& Economics Journal and Academy of Accounting and Financial Studies Journal. She serves on a number of advisory boards including the Jones International University Doctorate of Business Administration Advisory Board. She is a member of the American Institute of Certified Public Accountants, Institute of Management Accountants, Association of Government Accountants, Maryland Association of Certified Public Accountants, Association of Certified Fraud Examiners and the American Accounting Association. 
Orapin Duangploy, Ph.D., CPA, is Fiesta Professor of Accounting, University of Houston-Downtown. She has published numerous articles in such journals as International Journal of Accounting, Advances in International Accounting, Bank Accounting and Finance, and Journal of Education for Business. In addition, she has served on the editorial board of the Journal of Derivatives Accounting.

Dr. Clemense Ehoff Jr., CPA is the Vice President and Chief Financial Officer of R. K. Tongue Co., Inc., a Baltimore insurance agency. He holds a Ph. D in Business Administration from San Francisco's Golden Gate University. He has more than 30 years professional business experience and has held full-time faculty and adjunct faculty positions at universities predominantly in the Eastern United States. Over the last eight years, Dr. Ehoff has been involved in teaching accounting and tax courses in an online platform. He operates a consulting and tax practice. He has published articles in Elevator World, and other journals.

\section{REFERENCES}

1. Bonacum, L., \& N. Allen. (October 31, 2006). CCH Survey Sheds Light on What's Key to Attracting, Keeping Young CPAs at the Firm, and How Firms Match Up. CCH.com Retrieved March 9, 2008, from http://www.cch.com/press/news/2006/20061031t.asp

2. Bureau of Labor Statistics, U.S. Department of Labor, Occupational Outlook Handbook, 2006-07 Edition, Accountants and Auditors, Retrieved March 9, 2008 from http://www.bls.gov/oco/ocos001.htm

3. Clinton, B. D. (January 2007) Crisis! Strategic Finance. pp. 24-30.

4. Elliott, J. A. (February 26, 2007) Letter: Baruch is Committed to Accounting Education. Web CPA. Retrieved March 9, 2008 from http://www.webcpa.com/article.cfm?articleid=23423\&pg=acctoday

5. Findings From the CCH Young Accounting Professionals Survey (March 2007). Retrieved March 9, 2008 after completing registration information required at http://tax.cchgroup.com/getcontact/cfdefault.asp?formatid $=69$

6. IndiaPWire. (November 27, 2006). Shortage of Accountants in the US Leads to Tax Returns Prepared from India. IndiaPWire.com . Retrieved March 9, 2008 from http://www.indiaprwire.com/pressrelease/financialservices/200611251148.htm

7. Klein, P. (June 18, 2007) PhD Candidate Shortage in Accounting. Organizations and Markets. Retrieved March 9, 2008 from http://organizationsandmarkets.com/2007/06/18/phd-candidate-shortage-inaccounting/

8. Madison, R. L. (2005). The AICPA Vision Project and the 150 Hour Education Requirement: Consistency or Clash? New Accountant. Retrieved March 9, 2008, from http://www.newaccountantusa.com/newsFeat/is/is_cpa150.html

9. Maryland Association of Certified Public Accountants (MACPA) (August 2007) Enrollment Increases. MACPA.New Accountant USA (n.d.) Creating Value, Not Just Measuring It: The Vital Role of Management Accountants. New Accountant USA. pp. 7 - 15.

10. Noland, T. G., B. Francisco and D. Sinclair (March 2007) Pursuing a PhD in Accounting: What to Expect. The CPA Journal. Retrieved March 9, 2008 from http://www.nysscpa.org/cpajournal/2007/307/essentials/p66.htm

11. Penix, M. (July 24, 2006) Nationwide Accountant Shortage Hits New Orleans Hard. New Orleans City Business. Retrieved March 9, 2008 from http://findarticles.com/p/articles/mi_qn4200/is_20060724/ai_n16640721

12. Robert Half International (August 2007). The Red Carpet Treatment. Journal of Accountancy. pp. 36-39. Retrieved March 9, 2008 from http://www.aicpa.org/pubs/jofa/aug2007/rhi.htm

13. Sanders, B. (2005). The Supply of Accounting Graduates and the Demand for Public Accounting Recruits2005: For Academic Year 2003-2004. The American Institute of Certified Public Accountants (AICPA). Retrieved March 9, 2008, from http://ceae.aicpa.org/NR/rdonlyres/11715fc6-f0a7-4ad6-8d286285cbe77315/0/supply demandreport 2005.pdf 


\section{APPENDIX A: SURVEY INSTRUMENT}

Please put the following items in rank order indicating what is important to you when selecting a career. Please put the number 1 for the one most important to you and then put the number 2 for the one second most important to you and so on for all of the following 9 items. Feel free to add a 10th item if there is something of importance to you that is not listed below.

__a. Comprehensive resources (e.g., technology and software) to get the job done

b. Training and continued education provided and funded

c. Meaningful work in a stimulating environment

_d. Ability to work remotely

__e. Quality and affordable health coverage

__f. Compressed or flexible work weeks

_._. Advancement opportunities

__. Little or no travel

i. Salary

j. Other, which is

If you are an accounting major, then which of the following represents the impact of the 150-hour requirement on you?

Not going to take CPA exam

Going to get a Masters degree

__Other, which is

If you are not an accounting major, then what would it take to get you to become an accounting major?

__More money

__ Little or no travel

__other, which is

Note: Components of survey were either derived from or supported by the "Findings From the CCH Young Accounting Professionals Survey” (March 2007) and/or Robert Half (2007) 